Revised Draft

January 15, 2003

\title{
ECONOMETRIC STUDIES OF HIGHER EDUCATION
}

(Forthcoming in a special issue of the Journal of Econometrics)

$$
\text { by }
$$

\section{RONALD G. EHRENBERG*}

* Irving M. Ives Professors of Industrial and Labor Relations at Cornell University, Director of the Cornell Higher Education Research Institute (CHERI) and Research Associate at the National Bureau of Economic Research. I am grateful to the Andrew W. Mellon Foundation and the Atlantic Philanthropies (USA) Inc. for their financial support of CHERI. Without implicating them for what remains I am grateful to William Becker, David Breneman, Charles Clotfelter, Jeffrey Groen, Michael McPherson, Paula Stephan, Cecilia Rouse, John Siegfried, Myra Strober, Sarah Turner and Gordon Winston for their comments on an earlier version of the paper. However, all views expressed in this paper are strictly my own. 


\section{Introduction}

The economics of higher education goes back at least to Adam Smith, who suggested over 200 years ago in the Wealth of Nations that professors should get paid based upon the number of students enrolled in their classes (Smith, 1976). The econometrics of higher education is of much more recent vintage and emerged from the development of human capital theory and the efforts to estimate rates of return to education in the $1960 \mathrm{~s}$ and 1970s (Becker 1964, Mincer 1974).

In the sections that follow, I survey the various strands of the literature on the econometrics of higher education that have developed during the last 40 years and indicate how the papers in this issue fit into this literature. I discuss in turn the estimation of rates of return to higher education, studies of the academic labor market, studies relating to institutional behavior, and studies relating to higher education as an industry. As will quickly become clear, the vast majority of the papers in this issue fall within the first strand.

It is important at the outset that I stress to readers that the central econometric problem faced by higher education researchers who employ individual-level data is that of selection. Similarly, the central econometric problem faced by researchers who use market-level data is the difficulty of disentangling demand and supply shocks. Much of the challenge that empirical higher education researchers face is attempting to satisfactorily resolve these problems. 


\section{Estimating Rates of Return to Higher Education}

Literally hundreds of studies have estimated the private return to higher education.

One problem that has confounded researchers is that measures of student ability are often based on achievement test scores, which themselves are determined by completed schooling, which in turn is correlated with unobserved measures of ability. Karsten Hansen, James Heckman and Kathleen Mullen's paper in this volume presents a dynamic model that attempts to disentangle these issues.

Inasmuch as a large fraction of American college students begin their study at 2-year colleges (and a large share of these students end there as well), it has been natural for researchers to ask if the return to attending a 2-year college is the same as the return to attending a 4-year institution, and whether graduation from either a 2-year or a 4-year institutions has a "sheepskin effect" or if the return to higher education depends only on the number of credit hours earned (Grubb 1993, 1995, Jaeger and Page 1996, Kane and Rouse 1995a, 1995b). Similarly, as the share of students enrolling in college who are nontraditional, in the sense that their enrollment does not take place within a few years of high school graduation, increases, attention has also been directed towards estimating what the rate of return to higher education is for these students (Leigh and Gill 1997).

Within the 4-year college and university sector, studies have also focused on whether the return to higher education depends upon the type of institution that an individual attends. Studies undertaken in the 1980s and early 1990s, which used a variety of measures of institutional type, including expenditures per student and measures of average student test scores found ambiguous results (James et. al. 1989, Loury and 
Garman 1995). However, these studies did not model why students attended different types of institutions and thus were subject to selection bias problems.

More recent studies that attempted to control for selection by segmenting the universe of 4-year institutions into six groups based upon the average SAT scores of an institution's entering first-year students and whether the institution was public or private and then modeled students' decisions where to attend college using a Lee (1978) framework, found that attendance at the most selective private institutions confers extra economic advantages to students, in the form of higher early career earnings and higher probabilities of being admitted to the best graduate and professional schools (Ehrenberg and Brewer 1996, Brewer, Eide and Ehrenberg 1999, Eide, Ehrenberg and Brewer 1998). While Monks (2000b) reports similar conclusions, Dale and Krueger (1999), who control for selection more directly based upon knowledge of at what other schools students were accepted, obtain different results. They conclude that attendance at selective private institutions yields significant economic returns only for under represented minority students and students from lower-income families. The paper by Dan Black and Jeffrey Smith in this volume extends this literature using recently developed matching models and testing for the sensitivity of findings to the functional forms chosen.

Studies have also addressed the importance of other characteristics of colleges and universities for different groups of students. One set of studies has examined whether African American students who attend Historically Black Colleges and Universities have higher completion rates and higher early career earnings than students who attend other 4-year institutions, other factors held constant (Constantine, 1998, Ehrenberg and Rothstein 1994, Ehrenberg, Rothstein and Olsen, 1999). A second set has addressed 
whether traditionally single-sex women's colleges confer economic advantages on women who attend them, vis-à-vis comparable women who attend coeducational institutions and whether single-sex colleges alter the probabilities that female students will graduate from majors that are traditionally male dominated (Rothstein 1993, Solnick 1995).

Three papers in this volume are focused on how the location of the production of higher education affects outcomes in the labor market, such as migration and wages, keeping in mind that the private return to higher education is not necessarily the same as the social return. These questions are of great importance because many decisions about the production of higher education, including the provision of operating subsidies, are made at the state and local level, while college graduates may distribute themselves nationally or even internationally. In fact a rationale for why states invest in college and university education is that states may enjoy some of the returns from such investmentsthe more highly educated a state's workforce is the more productive it is and the higher the tax revenue that will likely accrue to the state.

To justify this rationale, two questions must be answered. First, does a state's investment in higher education lead to an increased representation of college-educated workers in the state's population? Second, does the concentration of college-educated workers lead to externalities in the form of higher wages for other workers or other social benefits that may follow from a more educated populace?

Groen's paper uses individual data to address how the state in which an individual attends college affects the individual's probability of finding employment in the state after graduation. The econometric challenge that he deals with is that students' attending 
college away from their home state may differ from their high school classmates in ways that are related to their propensity to move out of state, independent of their attending college out of state.

Bound, Groen, Kedzi and Turner's paper uses net migration data asks whether the production of college graduates in a state affects the stock of college-educated workers that live in the state. The key econometric problem they face is distinguishing between the case when high demand for college graduates in a state leads to the growth of the state's colleges and universities to meet this demand from the case when an expansion of colleges and universities leads to an expansion of employment of college-educated workers in the state. Using variation over states and across time, they find that the effect of the number of college degrees conferred in a state on the stock of the state's collegeeducated workforce is modest.

Turning to the question of how the concentration of college graduates in an area affects the productivity of all workers in an area, Enrico Morettti examines whether the earnings of different types of workers in a city depend upon the share of college graduates in the city's workforce. He finds that all types of workers' earnings are higher when the share of college graduates is higher, suggesting that there are social returns to education above and beyond the private returns. Unfortunately, the Bound et. al. paper suggests that states may be limited in their ability to capture such social returns through supply-side investments in colleges and universities.

Becker (1964) made the distinction between investments in general human capital and investments in specific human capital and asserted that employers would never pay for the latter because general human capital investments increase an individual's 
productivity at other places as well as at the current employer. Recent research has challenged this assertion (Barron, Berger and Black, 1999). Peter Cappelli's paper in the volume addresses why employers provide tuition assistance benefits for their employees. Cappelli shows that these benefits are not "paid for" by workers in the form of compensating lower wages or benefits. Rather employers who provide such benefits also pursue a number of other strategies that effectively bind employees to their firm, so that the firm can reap the benefits of the investments.

\section{Determinants of College Enrollment, College Graduation and Choice of} Major

A major concern of empirical research on the economics of higher education has been the role that various public policies have played in enhancing the college enrollment rates, persistence in college, and college graduation rates of high school graduates. Prior to the $1970 \mathrm{~s}$, the major federal programs that subsidized college attendance were targeted programs, such as the GI bill after WWII and other veterans benefits programs, that provided subsidies for veterans who attended college. Another major targeted program was the Social Security program, which provided benefits to children of deceased, disabled, or retired workers, who were between the ages of 19 and 23 and attending college (this program was eliminated in the early 1980s).

Angrist (1993) and Bound and Turner (2002) have studied the impact of veterans benefit programs on the college enrollment rates of veterans in the United States, while Lemiux and Card (2001) provided estimates of the impact of similar programs in Canada. Ehrenberg and Luzadis (1986) studied the impact of the Social Security Program on the 
amount families and students contributed to their education and the hours that enrolled students were employed while in school.

Starting in the 1970s, federal financial aid for students became more general with the introduction of the Basic Educational Opportunity (Pell) Grant program, the provision of subsidized loans, and the provision of employment opportunities through the College Work Study program. State financial aid for students primarily took the form of general subsidies to all students through keeping tuition at public universities low. Empirical economists naturally sought to estimate what the effect of the various federal financial aid programs, as well as the levels of public and private tuitions were on college enrollment rates and completion rates, both in the aggregate and for specific subgroups of the population (e.g. students from low-income families, underrepresented minorities). Manski and Wise (1983) was among the first careful studies that used longitudinal micro level data, other major studies included McPherson and Shapiro (1991), Kane (1994) and Dynarski (forthcoming). Much of the research focused on college enrollment decisions of students within a few years of college graduation, however recently Seftor and Turner (2002) have found that the Pell Grant program has had sizable effects on the college enrollment rates of potential students in their 20s and 30s.

In addition to providing indirect assistance to students by keeping tuition levels at state universities relatively low, states also provide direct assistance to students to help defray the cost of attending college. Historically most state grant aid has been based on the financial need of students. However, just as the federal government moved away from providing primarily need-based aid with the development of tax credits for education in the 1990s, a number of states also moved in this direction. Perhaps the most well known 
is Georgia and its HOPE Scholarship program. HOPE is awarded to Georgia high school graduates who graduated with a high school grade point average of at least a B and who enroll in higher education institutions in Georgia. Once enrolled in college, continued receipt of HOPE for subsequent year of study depends upon the enrolled students maintaining a grade point average of B in college.

Several recent studies have analyzed the impact of the HOPE program on college enrollment rates of Georgia high school graduates from different racial and family income groups, on where the students go to college, and on how the program has influenced students choice of majors after they enroll in college and attrition from college (Dynarski 2000, Cornwell and Mustard 2001, 2003, Cornwell, Mustard and Sridhar 2002, Dee and Jackson 1999). Other studies have more generally addressed how state financial aid policies and federal tax credits influence college enrollment rates (Dynarski 2002, Long 2002a). Avery and Kane (2002) have examined whether provision of information about college requirements and the availability of financial aid, along with enhanced counseling of students influences high school course selection, college application and college enrollment decisions of students from lower-income families.

Financial aid also comes from institutions and studies based on institutional data and surveys of individuals have addressed how institutional aid levels influence the decision of students to initially enroll at specific institutions to which they have been admitted (Ehrenberg and Sherman 1984, Seneca and Taussig 1987, Moore, Studenmund and Slobko, 1991, Curs and Singell 2002, Avery and Hoxby 2002, Linsenmeier, Rosen and Rouse 2002, van der Klauuw 2002) and to persist in these institutions (Singell 2001, Bettinger 2002). Many students work at least part-time while they are enrolled in college 
to help finance their educations and other research has addressed how college students' hours of employment influence their grade point averages and progress to degrees (Ehrenberg and Sherman 1987). The paper by Todd Stinebrickner and Ralph Stinebrickner in this issue also addresses this question.

Many students attending college, especially those attending 2-year institutions, live at home and commute to college. Not surprisingly, research has shown that high school graduates' college enrollment probabilities depend upon the proximity of colleges to their homes (Tinto 1985, Rouse 1994, Card 1995). Bridget Long's contribution to this volume, which estimates a model that simultaneously determines whether an individual attends college and, if so, which college he or she attends, integrates many of the themes we have discussed in this section, including the importance of college proximity in enrollment decisions.

Where students attend college depends, of course, on the criteria that colleges and universities use in admitting students. Research suggests that under represented minorities were given preference in admissions only at the nation's most selective private and public institutions in the 1980s and that at many selective institutions a narrowing of the extent of preference had taken place over time (Kane 1998, Bowen and Bok 1998). However, Long (this issue) suggests that by the mid 1990s such preferences were more widespread. Evidence from cohorts of students attending a set of selective private and public universities over a thirty year period suggests that scores on the much maligned Scholastic Assessment Test (SAT) do help to predict academic success and that these tests tend to over predict, rather than under predict African American students performance (Bowen and Bok 1998). Jesse Rothstein's paper in this volume shows, 
however, that the importance of SAT scores in predicting performance declines when characteristics of applicants' high schools are also included in the analysis. Given the importance of the SAT and the fact that retaking it often leads to higher test scores, Vigdor and Clotfelter (forthcoming) analyze what determines whether students take the SAT more than once and how colleges and universities use such information.

A series of court decisions and legislative actions in the 1990s, which prohibited affirmative action in admissions has led a number of states, including Florida, Texas and California, to adopt "percentage admit rules" for their public higher education institutions. In these states, students who graduate in the top x percent of their high school classes are guaranteed admission to flagship campuses. Kain and O'Brien (2001) analyze how the "top 10 percent" rule in Texas has affected the enrollment decisions of Texas high school graduates. Students cannot be admitted to an institution, however, unless they apply to that institution. In his paper in this volume, Mark Long addresses how these changes in admission rules have affected minority and other students' decisions as to which institutions to apply to within a state and their probabilities of also applying to out-of-state institutions.

Students must decide not only where to go to college but what specific subjects to study and what occupations to enter. Not surprisingly, students' choices of majors are heavily determined by the economic opportunities in the occupations for which a major prepares them, by the nonpecuniary conditions of employment in these occupations, by their academic aptitude and by the gender composition of people already in the occupation (Dynan and Rouse 1997, Berger 1998, Eide 1998, Eide and Waehrer 1998, Montmarquette, Cannings and Mahserekjian forthcoming, Turner and Bowen 1999). 
Peter Arciadiacono paper in this volume very carefully analyzes choices of college major in the context of a dynamic model of behavior that allows the returns to ability to differ across majors. Erica Field (2000) explores how the timing of career contingent financial aid influences whether law students will enter public interest careers.

One pressing issue facing American education in the decades ahead is how to generate a flow of highly qualified elementary and secondary school teachers. As other professional occupations, such as law, medicine, and business, that pay much more than teaching opened up to women during the last 30 years of the $20^{\text {th }}$ century, the ability (as measured by test scores) of young people entering the teaching profession declined (Manski 1987, Hanushek and Page 1994). Evidence indicates that teachers' academic ability is an important predictor of how much students learn (Ferguson 1991, Ferguson and Ladd 1996, Ehrenberg and Brewer 1995) While an obvious way to induce bright students to enter teaching careers would be to substantially increase the salaries of teachers, this would involve considerable increases in the revenue needed to finance elementary and secondary education. In his paper in the volume, Randall Reback analyzes whether the expansion at selective colleges and universities of teacher preparation programs that permit students to receive teaching credentials within 4 years would lead to an increased flow of academically talented college students to teach in public schools.

\section{The Academic Labor Market}

Studies of the labor market for college and university faculty begin with analyses of the flow of students into PhD study, the determinants of times to degree, the changing 
role and length of postdoctoral appointments in some fields, and the decision by new $\mathrm{PhDs}$ to accept academic rather than nonacademic positions. Much of the research in these areas conducted prior to 1990 is summarized in Ehrenberg $(1991,1992)$.

The determinants of times to degree and completion rates were postulated long ago to be functions of the job market for new PhDs and the patterns of financial aid the doctoral students received (Breneman 1976). Formal tests of these hypotheses, using longitudinal data on individuals enrolled in $\mathrm{PhD}$ programs in six fields at one university and competing risk duration models, were presented by Ehrenberg and Mavos (1995). Siegfried and Strock (2001) have presented evidence on the importance of financial aid patterns for times to degree for economics $\mathrm{PhD}$ students at a wide variety of institutions.

During the last 30 years the share of new PhDs granted by U.S universities to foreigners has increased substantially (Stephan et, al. 2002a). During the same period of time, the share of new PhDs granted to under represented minorities has remained low. Some have expressed concern that the growth in the foreign $\mathrm{PhD}$ student population has eliminated opportunities for underrepresented minorities to pursue $\mathrm{PhD}$ study. While there may be some truth to this belief, a study that addressed the admissions decisions of a set of major research universities found that, holding constant measures of student quality (grades and test scores), academic departments appeared to discriminate against foreign students and in favor of under represented minority students in the PhD program admissions process (Attiyeh and Attiyeh 1997). Others have expressed concern that foreign graduate students who serve as teaching assistants may adversely affect how much undergraduate students learn, however the evidence to support this contention is mixed (Borjas 2000, Fleisher, Hashimoto and Weinberg 2002) 
Numerous studies have analyzed the salaries of faculty members at a single institution or national samples of faculty to learn if salaries are related to measures of productivity (Hamermesh, Johnson and Weisbrod 1982, Hamermesh 1988) and if colleges and universities have monopsony power over their senior faculty (Ransom 1993, Hallack 1995, Monks and Robinson 2001). Others have analyzed whether there are gender differentials in earnings and promotion probabilities (Booth, Frank and Blackby 2001, Levin and Stephan 1998, Monks and Robinson 2000, Ginther and Hayes 1999, Hoffman 1976) and why females are underrepresented, relative to their share in the $\mathrm{PhD}$ population, at major research universities (Barbezat 1992). Still others have analyzed whether, holding other factors constant, faculty employed under collective bargaining agreements are paid more and have lower quit rates than faculty who are not covered by collective bargaining agreements (Barbezat 1989, Rees 1993, 1994, Ashraf 1997, Monks 2000a). Recently attention has also been directed to the effect of unions on the compensation of staff, other than faculty, at higher education institutions (Klaff and Ehrenberg 2002)

Studies also suggest that voluntary turnover of faculty is higher at institutions that pay lower average salaries (Ehrenberg, Kasper and Rees 1991) and that assistant professors demand and receive a compensating starting salary differential for positions that offer low probabilities of tenure (Ehrenberg, Pieper and Willis 1998). Other economists concerned with issues relating to the end of mandatory retirement for faculty that took place in 1994, have addressed how faculty productivity varies over the life cycle (Levin and Stephan 1991, Goodwin and Sauer 1995, Oster and Hamermesh 1998), how the end of mandatory retirement influenced retirement rates at universities (Ashenfelter and Card 
2002, Ehrenberg, Matier and Fontanella 2001, Clark, Ghent and Krebs 2001) and whether early retirement incentive programs for faculty covered by a defined benefit pension plan led to increased faculty retirements (Pencavel 2002). Finally, the impact of the growing cost of doing science on faculty employment and salary levels has been studied (Ehrenberg forthcoming).

\section{Models of University Behavior}

The modeling of the university as an organization producing multiple outputs and maximizing an objective function subject to constraints was first introduced in the work of Becker (1979), Garvin (1980) and James (1990). A unique feature of models of the university is that its customers (students) are also inputs into its production function (Rothshild and White 1995), which leads the prestige maximizing university to be concerned about the quality of its student body and to be engaged in an "arms race" of spending to make itself look more attractive to potential students and thus in a quest for ever increasing resources (Winston 1999).

Published measures of institutional rankings, the best known of which is the annual ranking of institutions for undergraduates conducted by U.S. News \& World Report, exacerbate the competition between institutions for top students as research indicates that applicant behavior is very much conditioned by the rankings (Monks and Ehrenberg 1999). The subjective ratings of $\mathrm{PhD}$ programs conducted by the National Research Council each decade or so have been analyzed in a hedonic framework to give institutions insight into how to improve their own departments' rankings (Ehrenberg and Hurst 1998, Becker, Toutkoushian and Dunbar 1998). 
Admission and financial aid decisions have been analyzed in the context of utility maximizing models of selective academic institutions and the framework yields information on which behavioral parameters and characteristics of the utility function should influence the extent to which an institution practices "preferential packaging" for different groups of applicants (Ehrenberg and Sherman 1984). These authors also illustrate how to estimate the key parameters needed to make such decisions. Focusing on admissions to graduate programs, Lawrence Marsh and Arnold Zellner show in their paper in this issue how Baysian analyses may be employed to aid in such decisions.

Linsenmeirer, Rosen and Rouse (2002) have estimated how changes in one institution's financial aid policies helped it to meet a goal of enhancing enrollments of low-income and underrepresented minority students. Institutions are ranked as more selective in the USNWR ranking scheme when they admit smaller fractions of their applicants and when higher fractions of the applicants they accept decide to enroll at their institution. One way to show improvement on both dimensions of selectivity is to admit more students via the early admissions route (Ehrenberg 2000, chapter 5) and as more selective colleges and universities have adopted this strategy the whole applications and admissions process has become more of a strategic game (Avery, Fairbanks and Zeckhauser 1998)

Models of the utility maximizing university have also been used to analyze how a change in federal support for graduate students impacts upon the size of an institution's graduate program, both in the aggregate and across fields (Ehrenberg, Rees and Brewer 1993), how institutions have altered their tuition and institutional financial aid policies in response to changes in the federal Pell grant program (McPherson, Schapiro and Winston 
1994, chapter 8) and whether the adoption of the HOPE scholarship program in Georgia affected tuition decisions of colleges and universities in the state (Long 2002b). Given concern about the nature of the academic production function, attempts have been made to test if "peer effects", the composition of the student body at an institution and the composition of an individual's more immediate peers (roommates, friends etc.) influence the amount that students learn as undergraduates and as medical students and how peer effects influence institutions' pricing decisions (Arcidiacono and Nicholson 2002, Goethals et. al. 1999, Zimmerman 1999, Zimmerman forthcoming, Sarcerdote 2001, Stinebrickner and Stinebrickner 2001, Kremer and Levy 2002, Winston and Zimmerman 2002, Epple, Romano and Sieg forthcoming).

A major source of funding for colleges and universities is annual giving from alumni, other individuals, corporations and foundations. Research has addressed how the financial aid given to students while they were enrolled influences their future giving (Clotfelter forthcoming, Dugan, Mullin and Siegfried 2000), how athletic teams records influence giving, both to athletics and the rest of the university (Baede and Sundberg 1996, Cunningham and Cochi-Ficano, 2002, Shulman and Bowen 2000, Turner, Meserve and Bowen 2001), whether too much success in growing endowments leads to lower levels of giving (Oster 2001) and how decisions are made to allocate giving across current operations, capital facilities and endowment building uses (Ehrenberg and Smith, forthcoming). Other researchers have asked whether success of big time athletic teams feeds back into improved academic credentials of future freshman classes (Mixon 1995) and what the factors are that the determine the athletics success of different institutions within a single collegiate athletic conference (Kotlyraenko and Ehrenberg (2000). 
Efforts have also been made to estimate production functions for teaching and research at colleges and universities, often with a view towards making statements about optimal scale and scope (de Groot, McMahon and Volkwein 1991, Dolan and Schmidt 1994, Dundar and Lewis 1995, Koshal and Koshal 1999). The substitutability of parttime for full-time faculty in the production of teaching in response to change in relative wages has also been examined (Tuckman and Katz 1981). Given that colleges and universities are not necessarily cost minimizers and thus may not necessarily be on their production frontiers, some researchers have analyzed higher education production functions using frontier estimation methods (Johnes and Johnes 1995, McMillan and Chan 2001, Izadi, H. et. al. 2002).

Many of the educational production function studies focus on numbers of degrees granted by or number of credit hours taken at an institution. A different strand of literature, exemplified by Becker and Powers (2001) addresses the important question of how students' class sizes influence their persistence in classes and the amount that they learn.

Another output of research universities is the commercialization of research through the production of patents and through licensing arrangements. Research has addressed the patent production function, the relationship between patent policies, research and teaching at a university and the productivity of licensing arrangements (Thursby and Thursby 2000, Thursby and Kemp 2002, Thursby, Jensen and Thursby, 2001, Stephan et. al. 2002b, Jensen and Thursby 2003). Finally researchers have studied the production function for research grants and the role that lobbying efforts and earmarks play (De Figueiredo and Silverman 2002, Payne and Siow 1998) 


\section{Higher Education as an Industry and Higher Education Governance}

Goldin and Katz (1999) provide an explanation of the historical evolution of American higher education during the 1890 to 1940 period. They provide explanations for the large average size higher education institutions, the coexistence of liberal arts colleges and large research universities, the substantial share of enrollments in the public sector, the location of professional schools within larger universities and the varying levels of state support for higher education. Focusing on the period since 1940, Hoxby (1997) analyzes the changing market structure of higher education and shows that the results of increased competition were higher average college quality and tuitions, greater between-college variations in tuition and student quality and less within college variation in student quality. Hoxby (2000) also investigates whether the consent degree signed by the Ivy League institutions in the early 1990s that prevented them from discussing the financial aid offers that they were planning to make to specific individuals who had been admitted to more than one of their institutions led to higher levels of financial aid and/or to more aid being awarded on a "merit" rather than a financial need basis.

A number of authors have focused on public higher education and provided models to explain differences across institutions and over time in state support to public higher education, differences in in-state tuition levels, differences in out-of-state tuition levels and differences in the proportion of undergraduate students at an institution enrolling from out-of-state (Quigley and Rubinfeld 1993, Greene 1994, Mixon and Hsing 1994, Groen and White 2001, Rizzo and Ehrenberg 2002). One theme that emerges from the work of Groen and White (2001) is the conflict between the interests of faculty and administrators at public universities and the interests of the state that is funding the 
institution. Lowry (2001a, 2001b) pursues this theme and shows that the governance structure of public higher education in a state, as represented by variables such as the methods by which trustees to public institutions are selected (elected or appointed), the number of separate governing boards for public higher education institutions in a state and the presence of coordinating boards influences the levels of tuition charged to in-state residents and expenditures per student.

Once one views higher education as a system, the interdependencies between institutions become more apparent. One relatively neglected research area has been the connection between 2-year and 4-year colleges. Two-year colleges serve as the point of entry for many students who otherwise would receive no higher education (democratization), but students who start in 2-year colleges may be less likely to ultimate complete 4-year degrees than students who start in 4-year colleges (diversion). Rouse (1995. 1998) asks whether on balance the presence of 2-year colleges enhances the overall education level of Americans. Hilmer (1997) addresses whether starting at a 2year college allows students to subsequently attend a higher quality 4-year institution than they would have been able to if they entered a 4-year institution directly after graduation from high school. Ehrenberg and Smith (2002) study transitions from 2-year to 4-year colleges within one large state system and develop and empirical methodology to estimate which 4-year colleges perform the best at educating the 2-year college students that transfer to them and which 2-year colleges' students that transfer are most likely to perform the best at the 4 -year institutions. 


\section{Concluding Remarks}

Any review of the literature in an area, no matter how comprehensive it may seem, reflects its author's interests and background. Readers familiar with my research will not be surprised that most of the literature that I have surveyed has been conducted by economists with backgrounds in labor and public economics and/or interests in the application of maximization models to the behavior of nonprofit institutions.

Literature reviews also reflect the set of research problems that researchers have studied and do not necessarily cover issues that few people have ventured to explore. So at the risk of going out on a limb, I will mention a few of the latter that I believe to be important areas for research. These relate to asset allocation at a point in time, inter temporal allocation of assets, and investments in development or fund-raising activities.

During the 1970s foundation reports, such as Ennis and Williamson (1976), and academic researchers, such as James Tobin (1974), encouraged universities to pursue a policy of basing their spending from their endowments on some fraction of the total longrun return that they expected their endowments to earn. The stock market boom of the late $1990 \mathrm{~s}$ and then its collapse at the start of the $21^{\text {st }}$ century suggests some problems with such spending rules. Moreover, little thought has been given by researchers as to what the optimal allocation of an academic institution's portfolio across asset classes should be and how this optimal allocation should vary with the risk the institution faces from its other revenue streams (tuition, state appropriations, annual giving, research funding, executive education income, etc.). Kaufman and Woglom (2002) have begun to address the latter question. 
Similarly, little attention has been directed toward and institutions' s optimal spending rule should vary with the expected growth rates of each of these other revenue sources. For example, one's intuition is that public higher education institutions that are faced with prospects of continued cut backs in their real level of state support per student should spend a smaller share of their endowment value each year than their counterparts that expect real state support to increase.

Furthermore, while it is well known that many academic institutions have great stores of financial assets, it is much less well known these institutions also have great stocks of physical capital (plant and equipment) assets. Financial and physical assets both support the academic programs of academic institutions, however, how institutions allocate their asset portfolio between these two classes of assets varies widely across institutions. For example, in the mid 1990s, Yale's endowment was approximately twice the replacement value of its physical capital assets while the comparable ratio for Northwestern was about .8 (Ehrenberg 2000, table 11.1). To date there has been only one study that sought to explain why the ratio of financial to physical plant assets varies across institutions (Siegfried and Getz 2003).

Finally, private giving has increasingly become an important source of revenue for America's private and public higher education institutions, providing them with over \$24 billion in revenue in the fiscal year ending June 30, 2001 (Pulley 2002). The research on annual giving that I described above does not address the issue of how institutions decide how much to invest in their development (or advancement) efforts to produce annual giving. Studies have concluded that the average cost of each dollar raised by academic institutions is less than 20 cents (Ehrenberg 2000, chapter 3). If the marginal 
costs of these efforts were approximately equal to the average costs, one might question why the academic institutions don't significantly expand their development activities. I have offered some explanations myself (Ehrenberg 2000, chapter 3), but econometric research on why the size of development operations varies across academic institutions and whether these sizes are anywhere near "optimal" has yet to be undertaken. 


\section{REFERENCES}

Abowd, J. 1984, An Econometric Model of the U.S. Market for Higher Education (Garland Publishers, New York NY)

Angrist, J. 1993, The Effect of Veterans Benefits on Education and Earnings,

Industrial and Labor Relations Review 46: 637-652.

Arcidiacono, P. and S. Nicholson 2002, Peer Effects in Medical School (National Bureau of Economic Research Working Paper No. 9025, Cambridge MA)

Ashenfelter, O. and D. Card 2002, Did the Elimination of Mandatory Retirement

Affect Faculty Retirement? American Economic Review 92: 957-980

Asraf, J. 1997, The Effect of Unions on Professors' Salaries: The Evidence Over Twenty Years, Journal of Labor Research 18: 439-450.

Attiyeh, G. and R. Attiyeh 1997, Testing for Bias in Graduate School Admissions, Journal of Human Resources 32: 524-548

Avery C. and C. Hoxby 2002, Do and Should Financial Aid Packages Affect

Students' College Choices?, paper presented at the NBER Conference on College

Decisions, How Students Actually Make Them and How They Could (Bretton Woods, $\mathrm{NH})$

Avery C. and T. Kane 2002, Student Perception of College Opportunities: The Boston COACH Program, paper presented at the NBER Conference on College Decisions, How Students Actually Make Them and How They Could (Bretton Woods, $\mathrm{NH})$ 
Avery, C., Fairbanks, A. and R. Zeckhauser 1998, An Assessment of Early Admission Programs at Highly Selective Undergraduate Institutions, JFK School of Public Policy Working Paper (Harvard University, Cambridge, MA)

Baade, R and J. Sundberg 1996, What Determines Alumni Generosity?, Economics of Education Review 15: 75-81.

Barbezat, D. 1989, The Effect of Collective Bargaining on Salaries in Higher Education, Industrial and Labor Relations Review 42: 443-455.

Barbezat, D. 1992, The Market for New Ph.D Economists, Journal of Economic Education 23: 262-276.

Barron, J., Berger, M. and D. Black 1999, Do Workers Pay for On-the Job Training, Journal of Human Resources 34: 235-252.

Becker, G. 1964, Human Capital: A Theoretical and Empirical Analysis (Columbia University Press, New York NY)

Becker, W. 1979, Professorial Behavior Given a Stochastic Reward Structure, American Economic Review 69: 110-117.

Becker, W., and J. Powers 2001, Student Performance, Attrition and Class Size

Given Missing Student Data, Economics of Education Review 20: 377 - 388.

Becker, W., Toutkoushian, R. and H, Dundar 1998, The National Research Council Graduate Program Rankings: What Are They Measuring, Review of Higher Education 21: 427-443.

Berger, M. 1988, Predicted Future Earnings and Choice of College Major, Industrial and Labor Relations Review 41: 418-429. 
Bettinger, E. 2002, How Financial Aid Affects Persistence in College, paper presented at the NBER Conference on College Decisions, How Students Actually Make Them and How they Could (Bretton Woods, NH)

Booth, A., Frank, J. and D. Blackaby 2001, Outside Offers and the Gender Pay Gap: Empirical Evidence from the UK Academic Labor Market (University of London Working Paper, London)

Borjas, G. 2000, Foreign Born Teaching Assistants and the Academic Performance of Undergraduates (National Bureau of Economic Research Working Paper No. 7635, Cambridge MA)

Bound, J. and S. Turner 2002, Going to War and Going to College: Did World War II and the G.I. Bill Increase Educational Attainment for Returning Veterans, Journal of Labor Economics 20: 784-816.

Bowen, W. and D. Bok 1998, The Shape of the River: Long-Term Consequences of Considering Race in College and University Admissions (Princeton University Press, Princeton NJ)

Breneman, D. 1976, The PhD Production Process, in J.Fromkin, D. Jamison and R. Radner eds., Education as an Industry (Ballinger, Cambridge MA)

Brewer, D., E. Eide and R. Ehrenberg 1999, Does it Pay to Attend an Elite Private College? Cross-Cohort Evidence on the Effects of College Type on Earnings, Journal of Human Resources 34: 104-123

Card, D. 1995, Using Geographic Variation in College Proximity to Estimate the Returns to Schooling, in L. Christofides et. al. ed. Aspects of Labour Market Behavior: Essays in Honor of John Vanderkamp (University of Toronto Press, Toronto) 
Clark, R., Ghent, L. and J. Krebs 2001, Faculty Retirement Behavior at Three North Carolina Universities, in R. Clark and B. Hammond eds. To Retire or Not?

Retirement Policies and Practices in Higher Education (University of Pennsylvania Press, Philadelphia PA)

Clotfelter, C. forthcoming, Alumni Giving to Elite Private Colleges and Universities, Economics of Education Review.

Constantine, J. 1995, The Effect of Attending Historically Black Colleges and Universities on Future Wages of Black Students, Industrial and Labor Relations Review: 48: 531-546.

Cornwell, C. and D. Mustard 2001, The Distributional Impacts of Lottery-Funded Merit-Based Scholarships: Evidence From Georgia (University of Georgia Terry School of Business Working Paper, Athens GA)

Cornwell, C. and D. Mustard 2003, Merit Based Financial Aid and Car Sales (Paper presented at the Allied Social Science Association Meetings, Washington DC)

Cornwell, C., Mustard D. and D. Sridhar 2002, The Enrollment Effects of MeritBased Financial Aid: Evidence from Georgia's HOPE Scholarship (University of Georgia Terry School of Business Working Paper, Athens GA)

Cunningham, B. and C. Cochi-Ficano 2002, "The Determinants of Donative Revenue Flows from Alumni of Higher Education: An Empirical Inquiry, Journal of Human Resources 37: 540-569.

Curs, B. and L. Singell 2002, An Analysis of the Application and Enrollment Process for In-State and Out-of-State Students at a Large Public University, Economics of Education Review 21: 111-124. 
Dale, S. and A. Krueger 2002, Estimating the Payoff to Attending a More

Selective College: An Application of Selection on Unobservables, Quarterly Journal of Economics 117: 1491-1528.

Dee, T. and L. Jackson 1999, Who Loses Hope? Attrition from Georgia's College Scholarship Program, Southern Economic Journal 66: 379-390.

De Figueiredo, J. and B. Silverman 2002, Academic Earmarks and the Returns to Lobbying (National Bureau of Economic Research Working Paper No. 9064, Cambridge MA)

De Groot, H., McMahon, W. and J. Volkwein 1991, The Cost Structure of American Research Universities, Review of Economics and Statistics 73: 424-431

Dolan, R. and R. Schmidt 1994, Modeling Institutional Production of Higher Education, Economics of Education Review 13: 197-213.

Dundar, H, and D. Lewis 1995, Departmental Productivity in American Universities: Economies of Scale and Scope, Economics of Education Review14: 119144.

Dugan, K., Mullin, C. and J. Siegfried 2000, Undergraduate Financial Aid and Subsequent Giving Behavior, (Williams Project on Higher Education Working Paper DP57, Williams College, Williams MA)

Dynan, K. and C. Rouse 1997, The Under Representation of Women in Economics: A Study of Economics Majors, Journal of Economic Education 28: 350-368.

Dynarski, S. 2000, Hope for Whom? Financial Aid for the Middle Class and its Impact on College Attendance, National Tax Journal 53: 629-661. 
Dynarski, S. 2002, The Consequences of Merit Aid (National Bureau of

Economic Research Working Paper No. 9400, Cambridge MA)

Dynarski, S. forthcoming, Does Aid Matter? Measuring the Affects of Student

Aid on College Attendance and Completion, American Economic Review

Ehrenberg, R. 1991, Academic Labor Supply, in C. Clotfelter, R. Ehrenberg, M.

Getz and J. Siegfried, Economic Challenges in Higher Education (University of Chicago

Press, Chicago IL)

Ehrenberg, R. 1992, The Flow of New Doctorates, Journal of Economic

Literature 30: 830-875

Ehrenberg, R. 2000, Tuition Rising: Why College Costs So Much (Harvard

University Press, Cambridge MA)

Ehrenberg, R. forthcoming, Studying Ourselves: The Academic Labor Market, Journal of Labor Economics

Ehrenberg, R. and D. Brewer 1995, Did Teachers' Verbal Ability and Race

Matter in the 1960s? Coleman Revisited, Industrial and Labor Relations Review 14: 1-21.

Ehrenberg, R. and D. Brewer 1996, Does it Pay to Attend an Elite Private

College? Evidence from the Senior Class of 1980, Research in Labor Economics 15: 239271.

Ehrenberg, R., Cheslock, J. and J. Epifantseva 2001, Paying Our Presidents: What Do Trustees Value?, Review of Higher Education 25: 15-37.

Ehrenberg, R. and P. Hurst 1998, The 1995 Ratings of Doctoral Programs: A Hedonic Model, Economics of Education Review 17: 137-148. 
Ehrenberg, R., Kasper, H. and D. Rees 1991, Faculty Turnover in American Colleges and Universities, Economics of Education Review 10: 99-110.

Ehrenberg, R. and R. Luzadis 1986, The Social Security Student Benefit Program and Family Decisions, Economics of Education Review 5: 119-128

Ehrenberg, R., Matier, M. and D. Fontanella 2001, Cornell University Confronts the End of Mandatory Retirement, in R. Clark and B. Hammond eds, To Retire or Not? Retirement Policy and Practice in Higher Education (University of Pennsylvania Press, Philadelphia, PA)

Ehrenberg, R. and Mavros, P. 1995, Do Doctoral Students' Financial Support Patterns Affect Their Times-To-Degree and Completion Probabilities?, Journal of Human Resources 30: 581-609.

Ehrenberg R., Pieper, P. and R. Willis 1998, Do Economics Departments with Lower Tenure Probabilities Pay Higher Faculty Salaries?, Review of Economics and Statistics 80: 503-512.

Ehrenberg, R., Rees, D. and Brewer, D. 1993, Institutional Responses to External Support for Graduate Students, Review of Economics and Statistics 75: 671-682.

Ehrenberg, R. and M. Rizzo 2002, Causes and Consequences of Differences in InState and Out-of-State Tuition at Public Institutions of Higher Education, paper presented at the NBER Conference on College Decisions, How Students Actually Make Them and How They Could (National Bureau of Economic Research, Bretton Woods, NH)

Ehrenberg, R. and D. Rothstein 1994, Do Historically Black Colleges and Universities Confer Unique Advantages on Black Students? An Initial Analysis, in R. 
Ehrenberg ed. Choices and Consequences: Contemporary Policy Issues in Education (ILR Press, Ithaca NY)

Ehrenberg, R., D. Rothstein and R. Olsen 1999, Do Historically Black Colleges and Universities Enhance the College Attendance of African-American Youths, in P. Moen, D. Demster-McClain and H. Walker Eds. A Nation Divided (Cornell University Press, Ithaca NY)

Ehrenberg, R. and D. Sherman 1984, Optimal Financial Aid Policies for a Selective University, Journal of Human Resources 19: 202-230.

Ehrenberg, R. and D. Sherman 1987, Employment While in College, Academic Achievement and Postcollege Outcomes- A Summary of Results, Journal of Human Resources 22: 1-23.

Ehrenberg, R. and C. Smith forthcoming, The Sources and Uses of Annual Giving at Selective Private Research Universities and Liberal Arts Colleges, Economics of Education Review.

Ehrenberg, R. and C. Smith 2002, Within State Transitions from 2-Year to 4-Year Public Institutions (National Bureau of Economic Research Working Paper No. 8792, Cambridge MA)

Eide, E. 1994, College Major Choice and Changes in the Gender Wage Gap, Contemporary Economic Policy 12: 55-64.

Eide, E., D. Brewer and R. Ehrenberg 1998, Does it Pay to Attend an Elite Private College? Evidence on the Effect of Undergraduate College Quality on Graduate School Attendance, Economics of Education Review 17: 371-376. 
Eide, E. and G. Waehrer 1998, The Role of the Option Value of College Attendance in College Major Choice, Economics of Education Review 17: 73-82.

Ennis, R. and P. Williamson 1976, Spending Policy for Educational Endowments: A Research and Publication Project of the Common Fund (The Common Fund, New York NY).

Epple, D., Romano, R. and H. Sieg forthcoming, Peer Effects, Financial Aid and Selection of Students Into Colleges and Universities: An Empirical Analysis, Journal of Econometrics

Ferguson, R. 1991, Paying for Public Education: New Evidence on How and Why Money Matters, Harvard Journal of Legislation 28: 465-497.

Ferguson, R. and H. Ladd 1996, How and Why Money Matters, in H Ladd ed. Holding Schools Accountable: Performance-Based Reform in Education (Brookings Institution, Washington DC): 265-298.

Field, E. 2002, Educational Debt Burden and Career Choice: Evidence From a Financial Aid Experiment at NYU Law School (Princeton University Industrial Relations Section Working Paper No. 469, Princeton NJ)

Fleisher, B., Hashimoto, M and B. Weinberg 2002, Foreign GTAs Can be Effective Teachers of Economics, Journal of Economic Education 33(4): 295-325.

Garvin, D. 1980, The Economics of University Behavior (Academic Press, New York NY)

Ginther, D. and K. Hayes 1999, Gender Differences in Salary and Promotion in the Humanities, American Economic Review 89: 397-402. 
Goethals, G., Winston, G. and D. Zimmerman 1999, Students Educating Students: The Emerging Role of Peer Effects in Higher Education (Williams Project on Higher Education Working Paper DP-50, Williams College, Williamstown MA)

Goldin, C. and L. Katz 1999, The Shaping of Higher Education: The Formative Years in the United States, 1890 to 1940, Journal of Economic Perspectives 13: 37-62.

Goodwin, T. and R. Sauer 1995, Life Cycle Productivity in Academic Research: Evidence from Cumulative Publication Histories of Academic Economists, Southern Economic Journal 61: 728-742.

Greene, K. 1994, The Public Choice of Nonresident Tuition Levels, Public Interest 78: 231-240

Groen, J and White, M. 2001, In-State vs. Out-of-State Students: The Divergence of Interests Between Public Universities and State Governments (University of Michigan Economics Department Working Paper, Ann Arbor MI)

Grubb, W. 1993, The Varied Economic Returns to Postsecondary Education: New Evidence from the Class of 1972, Journal of Human Resources 28, 365-382.

Grubb, W. 1995, Postsecondary Education and the Sub-Baccalaureate Labor Market; Corrections and Extensions, Economics of Education Review 14, 285-299

Hallock, K. 1995, Seniority and Monopsony in the Academic Labor Market, American Economic Review 85:654-657.

Hamermesh, D. 1989, Why Do Individual-Effects Models Perform So Poorly? The Case of Academic Salaries, Southern Economics Journal 56: 39-45.

Hamermesh, D., Johnson, G. and B. Weisbrod 1982, Scholarship, Citations and Salaries: Economic Rewards in Economics, Southern Economic Journal 49: 472-481. 
Hanushek, E. and R. Page 1994, Understanding Entry into the Teaching

Profession, in R. Ehrenberg ed. Choices or Consequences: Contemporary Policy Issues in Education (ILR Press, Ithaca, NY): 12-28

Hilmer, M. 1997, Does Community College Attendance Provide a Strategic Path to a Higher Quality Education, Economics of Education Review 16: 59-68.

Hoffman, E. 1976, Faculty Salaries: Is There Discrimination by Sex, Race and Discipline? Additional Evidence, American Economic Review 66: 196-198.

Hoxby, C. 1997, How the Changing Market Structure of U.S. Higher Education Explains College Tuition (National Bureau of Economic Research Working Paper No. 6323, Cambridge MA)

Hoxby, C. 2000, Benevolent Colluders? The Effects of Antitrust Actions on College Financial Aid and Tuition (National Bureau of Economic Research Working Paper No. 7754, Cambridge MA)

Izadi, H. et. al. 2002, Stochastic Frontier Estimation of a CES Cost Function: The Case of Higher Education in Britain, Economics of Education Review 21: 63-71.

Jaeger, D. and M. Page 1996, Degrees Do Matter: New Evidence on Sheepskin Effects in the Returns to Education, Review of Economics and Statistics 78, 733-740. James, E. 1990, Decision Processes and Priorities in Higher Education, in S. Hoenack and E. Collins eds, The Economics of American Universities (State University of New York Press, Albany NY)

James, E. et al. 1989, College Quality: Where Should You Send Your Children to College? American Economic Review 79: 247-252 
Jensen, R. and M. Thursby 2003, Patent Policies, University Research, and Education in the U.S. (paper presented at the Allied Social Science Association Meetings, Washington DC)

Johnes, J. and G. Johnes 1995, Research Funding and Performance in UK University Department of Economics: A Frontier Analysis, Economics of Education Review 14: 301-314.

Kain, J. and D. O'Brien 2001, Hopwood and the Top 10 Percent Law: How They Have Affected College Enrollment Decisions of Texas High School Graduates (Cecil and Ida Green Center for the Study of Science and Society Working Paper, University of Texas at Dallas, Dallas TX)

Kane, T. 1998, Racial and Ethnic Preferences in College Admissions, in C. Jencks and M. Phillips eds. The Black-White Test Score Gap (Brookings Institution, Washington DC)

Kane, T. 1994, College Attendance by Blacks Since 1970: The Role of College Costs, Family Background and the Returns to Education, Journal of Political Economy 102: 878-911.

Kane, T. and C. Rouse 1995, Comment on W. Norton Grubb, "The Varied Economic Returns to Postsecondary Education: New Evidence from the Class of 1972", Journal of Human Resources 30: 205-221 (1995a)

Kane, T. and C. Rouse 1995, Labor-Market Returns to Two- and Four-Year Colleges, American Economic Review 85: 600-614 (1995b) 
Kaufman, R. and G. Woglom 2002, Incorporating Total Institutional Risk in the Management of College and University Endowments (Smith College Economics Department Working Paper, Northampton MA)

Klaff, D. and R. Ehrenberg 2002, Collective Bargaining and Staff Salaries in American Colleges and Universities (National Bureau of Economic Research Working Paper No. 8861, Cambridge, MA)

Koshal, R. and M. Koshal 1999, Economies of Scale and Scope in Higher Education: A Case of Comprehensive Universities, Economics of Education Review 18: 269-277.

Kotlyraenko, D. and R. Ehrenberg 2000, Ivy League Athletics Performance: Do Brains Win?, Journal of Sports Economics 1: 139-150.

Kremer, M. and D. Levy 2002, Peer Effects from Alcohol Use Among College Students (Harvard University Economics Department mimeograph, Cambridge MA) Lee L. 1978, Unionism and Relative Wage Rates: A Simultaneous Equations Model with Qualitative and Limited Dependent Variables, International Economic Review 19: 415-433.

Leigh, D. and A. Gill 1997, Labor Market Returns to Community College:

Evidence for Returning Adults, Journal of Human Resources 32: 334-53

Lemieux, T. and D. Card 2001, Education, Earnings and the 'Canadian G.I. Bill', Canadian Journal of Economics 34: 312-344.

Levin, S. and P. Stephan 1991, Research Productivity Over the Life Cycle:

Evidence for Academic Scientists, American Economic Review 81: 114-132 
Levin, S. and P. Stephan 1998, Gender Differences in Rewards to Publishing in Academe: Science in the 1970s, Sex Roles: A Journal of Research 38: 1049-1064.

Linsenmeier, D., Rosen, H. and C. Rouse 2002, Financial Aid Policies and College Enrollment Decisions: An Econometric Case Study (National Bureau of Economic Research Working Paper No. 9228, Cambridge MA)

Long, B. 2002a, The Impact of Federal Tax Credits for Higher Education Expenses, paper presented at the NBER Conference on College Decisions, How Students Actually Make Them and How They Could (Bretton Woods, NH)

Long, B. 2002b, How Do Financial Aid Policies Affect Colleges?, The Institutional Impact of the Georgia Hope Scholarship Program, (Harvard Graduate School of Education Working Paper, Cambridge MA)

Loury, L. and D. Garman 1995, College Selectivity and Earnings, Journal of Labor Economics 13: 289-308.

Lowry, R. 2001a, The Effects of State Political Interests and Campus Outputs on Public University Revenues, Economics of Education Review 20: 105-119

Lowry, R. 2001b. Governmental Structure, Trustee Selection and Public University Prices and Spending: Multiple Means to Similar Ends, American Journal of Political Science 45: 845-861.

Manski, C. and D. Wise 1983, College Choice in America (Harvard University Press, Cambridge, MA)

Manski, C. 1987 Academic Ability, Earnings and the Decision to Become a Teacher: Evidence from the High School Class of 1972, in D. Wise ed. Public Sector Payrolls (University of Chicago Press, Chicago IL): 291-312 
McMillan, M. and W. Chen 2001, Comparing University Efficiency Using

Stochastic and Non-stochastic Measures (University of Alberta Working Paper,

Edmonton, Alberta)

McPherson, M. and M. Schapiro 1991, Does Student Aid Affect College

Enrollment- New Evidence on a Persistent Controversy, American Economic Review 81: 309-318

McPherson, M., Schapiro M. and G. Winston 1994, Paying the Piper:

Productivity, Incentives and Financing in U.S. Higher Education (University of Michigan Press, Ann Arbor MI)

Mincer, J. 1974, Schooling Experience and Earnings (Columbia University Press, New York, NY)

Mixon, F. 1995, Athletics vs. Academics: Rejoining the Evidence from SAT

Scores, Education Economics 3: 277-283.

Mixon, F. and Y. Hsing 1994, The Determinants of Out-of-State Enrollments in Higher Education: A Tobit Analysis, Economics of Education Review 13: 329-335.

Monks, J. 2000(a), Unionization and Faculty Salaries: New Evidence from the 1990s, Journal of Labor Research 21: 305-314.

Monks, J. 2000(b), The Returns to Individual and College Characteristics:

Evidence from the National Longitudinal Survey of Youth, Economics of Education Review 19: 279-289.

Monks, J. and M. Robinson 2000, Gender and Racial Earnings Differentials in Academic Labor Markets, Economic Inquiry 38: 662-671. 
Monks, J. and R. Ehrenberg 1999, The U.S News \& World Report Rankings: Why Do They Matter, Change 31(6): 42-51,

Monks, J and M. Robinson 2001, The Returns to Seniority in Academic Labor Markets, Journal of Labor Research 22: 415-427.

Montmarque, C., Cannings, K. and S. Mahseredjian forthcoming, How Do Young People Choose College Majors?, Economics of Education Review.

Moore, R., Studenmund, A. and T, Skibko 1991, The Effect of the Financial Aid Package on the Choice of a Selective College, Economics of Education Review 10: 311321.

Oster, S. 2001, The Effect of University Endowment Growth on Giving: Is There Evidence of Crowding Out? (Yale University School of Management Working Paper No. ES-10, New Haven, CN)

Oster, S. and D. Hamermesh 1998, Age and Productivity Among Economists, Review of Economics and Statistics 80: 154-156.

Payne, A. and A. Siow 1998, Estimating the Effects of Total Research Funding on Universities Using Alumni Representation on Congressional Appropriations Committees (University of Toronto Economics Department Working Paper, Toronto, Canada)

Pencavel, J. 2001, The Response of Employees to Severance Incentives: The University of California Faculty", Journal of Human Resources 36: 58-84.

Pulley, J. 2002, Private Giving to Colleges Surpassed Expectations in 2001-002, Chronicle of Higher Education (April 5): A24 
Quigley, J. and D. Rubinfeld 1993, Public Choice in Public Higher Education, in C. Clotfelter and M. Rothschild eds. Studies of Supply and Demand in Higher Education (University of Chicago Press, Chicago IL): 243-283.

Ransom, M. 1993, Seniority and Monopsony Power in the Academic Labor Market, American Economic Review 83: 221-233.

Rees, D. 1993, The Effects of Unionization on Faculty Salaries and Compensation: Estimates from the 1980s, Journal of Labor Research 14: 399-422

Rees, D. 1994, Does Unionization Increase Faculty Retention, Industrial Relations 33: 297-321.

Rothschild, M. and L. White 1995, The Analytics of Pricing in Higher Education and Other Services in Which Customers Are Inputs, Journal of Political Economy 103:573-586

Rothstein, D. 1993, Generating Equality? An Economic Analysis of Labor Market and Educational Outcomes of Single-Sex Versus Coed College Education (unpublished Cornell University Masters Thesis, Ithaca NY)

Rouse, C. 1994, What to do After High School? Two-Year vs. Four-Year College Enrollment Decisions, in R. Ehrenberg ed. Choices and Consequences: Contemporary Policy Issues in Education (ILR Press, Ithaca NY): 59-88.

Rouse, C. 1995, Democratization or Diversion? The Effect of Community Colleges on Educational Attainment, Journal of Business Economics and Statistics, 13: 217-224. 
Rouse, C. 1998, Do Two-Year Colleges Increase Overall Educational

Attainment? Evidence From the States, Journal of Policy Analysis and Management, 17: 595-620.

Sarcerdote, B. 2001, Peer Effects with Random Assignment: Results for Dartmouth Roommates, Quarterly Journal of Economics 116: 681-704.

Seftor, N. and S. Turner 2002, Back to School: Federal Student Aid Policy and Adult College Enrollment, Journal of Human Resources 37: 336-352

Seneca, J. and M. Taussig 1987, The Effects of Tuition and Financial Aid on the Enrollment Decisions at a State University, Research in Higher Education 26:337-362

Shulman, J and W. Bowen 2000, The Game of Life (Princeton University Press, Princeton NJ)

Siegfried, J. and M. Getz 2003, The Sensitivity of Factor Proportions to Relative Prices in Higher Education (Vanderbilt Economics Department Working Paper, Nashville $\mathrm{TN})$

Siegfried, J. and Stock, W. 2001, So You Want to Earn a Ph.D in Economics: How Long Do You Think it Will Take?, Journal of Human Resources 36: 364-378 Singell, L. 2001, Come and Stay a While: Does Financial Aid Effect Enrollment and Retention at a Large Public University (University of Oregon Department of Economics Working Paper, Eugene OR)

Smith, A. 1976, The Wealth of Nations (University of Chicago Press, Chicago IL)

Solnick, S. 1995, Changes in Women's Majors from Entrance to Graduation at Women's and Coeducational Colleges, Industrial and Labor Relations Review 48: 505514. 
Stephan, P. et. al. 2002, Survey of Foreign Recipients of U.S. PhDs, Science 295: 2211-2212 (2002a).

Stephan, P. et. al. 2002, Patenting and Publishing: Substitutes or Complements for University Faculty? , Paper presented at the May 2002 NBER Higher Education Meeting (Cambridge MA) (2002b)

Stinebrickner, T. and R. Stinebrickner, 2001, Peer Effects Among Students from Disadvantaged Backgrounds (CIBC Human Capital and Productivity Project Working Paper 2001-3, University of Western Ontario, London Ontario)

Thursby, J., Jensen, R., and M. Thursby 2001, Objectives, Characteristics and Outcomes of University Licensing: A Survey of Major U.S. Universities, Journal of Technology Transfer 26: 59-72

Thursby, J. and S. Kemp 2002, Growth and Productive Efficiency of Intellectual Property Licensing, Research Policy 31: 109-124.

Thursby, J and M. Thursby 2000, Who is Selling the Ivory Tower? Sources of Growth in University Licensing (paper presented at the NBER Higher Education Working Group Meeting, Cambridge MA)

Tinto, V. 1985, College Proximity and Rates of College Attendance, American Education Research Journal 10: 273-299.

Tobin, J. 1974, What is Permanent Endowment Income? , American Economic Review 64: 427-432.

Tuckman, H. and D. Katz, Estimation of Relative Elasticities of Substitution and Relative Compensation for Part-time Faculty, Economics of Education Review 1: 359366. 
Turner, S. and W. Bowen 1999, Choice of Major: The Changing (Unchanging) Gender Gap, Industrial and Labor Relations Review 52: 289-313.

Turner, S., Meserve, L. and W. Bowen 2001, Winning and Giving: Football Results and Alumni Giving at Selective Private Colleges and Universities, Social Science Quarterly 82: 812-826.

van der Klauuw, W. 2002, Estimating the Effects of Financial Aid Offers on College Enrollment: A Regression Discontinuity Approach, International Economic Review 43: 1249-1287.

Vigador, J. and C. Clotfelter forthcoming, Retaking the SAT, Journal of Human Resources.

Winston, G. 1999, Subsidies, Hierarchies and Peers: The Awkward Economics of Higher Education, Journal of Economic Perspectives 13: 13-36.

Winston, G. and D. Zimmerman 2002, Peer Effects in Higher Education, paper presented at the NBER Conference on College Decisions: How Students Actually Make Them and How They Could (Bretton Woods, NH).

Zimmerman, D. 1999, Peer Effects in Academic Outcomes: Evidence from A Natural Experiment (Williams Project on Higher Education Working Paper D-52, Williams College, Williamstown, MA).

Zimmerman, D. forthcoming, Peer Effects in Academic Outcomes: Evidence from a Natural Experiment, Review of Economics and Statistics. 
